Canadian University Music Review

Canadian University Music Review

Revue de musique des universités canadiennes

\title{
So You Want to Be a Rock'n'Roll Scholar - Well You Need to Get an MBA
}

\section{Rob Bowman}

Volume 18, numéro 1, 1997

Crossing Borders: Interdisciplinary Studies by Canadian Scholars Franchir les frontières : études interdisciplinaires de chercheurs canadiens

URI : https://id.erudit.org/iderudit/1014820ar

DOI : https://doi.org/10.7202/1014820ar

Aller au sommaire du numéro

Éditeur(s)

Canadian University Music Society / Société de musique des universités canadiennes

ISSN

0710-0353 (imprimé)

2291-2436 (numérique)

Découvrir la revue

Citer cet article

Bowman, R. (1997). So You Want to Be a Rock'n'Roll Scholar — Well You Need to Get an MBA. Canadian University Music Review / Revue de musique des universités canadiennes, 18(1), 52-65. https://doi.org/10.7202/1014820ar

\section{Résumé de l'article}

Stax Records was a record label based in Memphis, Tennessee from the late 1950s through December 1975, when it was forced into involuntary bankruptcy. "So You Want to Be a Rock and Roll Scholar - Well You Need to Get an MBA" uses Stax Records as a case study to problematize what has often been a tendency within popular music scholarship to attempt to understand the political economy of the record industry primarily via the mechanical application of Marxist theory on a macro level. In looking in detail at the relationship between CBS Records and Stax from 1972 through 1975, the author concludes that to fully understand the nature of the distribution agreement between the two companies, its ramifications, and the consequent subsequent actions of the various principals involved, all of which eventually led to Stax's bankruptcy, one needs to take into account on a micro level the different modi operandi of independent and major labels, differences in the retail world of black and white America, and individual agency. Finally, all of the above needs to be considered very specifically within a temporal framework. The final conclusions prove to be significantly different from what would have resulted from solely from a Marxist analysis on a macro level.
All Rights Reserved (C Canadian University Music Society / Société de musique des universités canadiennes, 1997
Ce document est protégé par la loi sur le droit d'auteur. L'utilisation des services d'Érudit (y compris la reproduction) est assujettie à sa politique d'utilisation que vous pouvez consulter en ligne.

https://apropos.erudit.org/fr/usagers/politique-dutilisation/ 


\section{SO YOU WANT TO BE A ROCK'N'ROLL SCHOLAR - WELL YOU NEED TO GET AN MBA}

\section{Rob Bowman}

It is by now an accepted tenet that the political economy surrounding any musical idiom has large-scale overt and covert effects that influence, to use Christopher Small's term, the "musicking"1 choices made by both producers and consumers. With that in mind, most popular music scholars have taken a perspective largely borrowed from Marx as the basis for analyzing the activities that occur within the marketplace. The underlying basis of this particular application of Marxian theory is that human action and historical processes are almost entirely structurally or systematically determined. One paradigm commonly employed has viewed major and independent record labels as engaged in an endless cycle of conflict and contestation for control of various parts of the marketplace. This approach is readily evident, for example, in the works of Peter Wicke, Simon Frith, Jonathan Kamin, ${ }^{2}$ and, in what is perhaps its earliest manifestation with reference to rhythm and blues and rock and roll, Charlie Gillett's ground breaking 1970 study The Sound of the City: The Rise of Rock ' $N$ ' Roll. ${ }^{3}$

This is an approach that I, myself, have often taken and I believe, in general, that it has great utilitarian value when applied to the motivations and tendencies within the record industry on general and large-scale levels. In fact, it is one possible paradigm through which to explore the material that follows. That said, the application of this paradigm tends to preclude recognizing potentially significant agency for real people to take individually unique action that may not be readily predictable or understandable with reference to general patterns within the larger system. Further, automatically viewing major and independent labels as only being in constant conflict and antipathy can obscure profound nuances at the micro level with regard to individual scenarios that may actually obviate what might seem to be obvious conclusions from a macro Marxian perspective.

1 Christopher Small, Music of the Common Tongue: Survival and Celebration in Afro-American Music (London: John Calder, 1987).

2 Peter Wicke, Rock Music: Culture, Aesthetics, and Sociology (Cambridge: Cambridge University Press, 1990); Simon Frith, several works, among them, Sound Effects: Youth Leisure, and the Politics of Rock'n'Roll (New York: Pantheon, 1981); Jonathan Kamin, Rhythem and Blues in White America: Rock and Roll as Acculturation and Perceptual Learning (Ph.D. diss., Princeton University, 1975).

3 Charlie Gillett, The Sound of the City: The Rise of Rock'N'Roll (London: Souvenir Press, 1970). 
Let me briefly explain how this paper originated. Trained as an ethnomusicologist I have always attempted to understand popular music as a cultural gesture. Ethnomusicology, by definition, has been a discipline engaged in border crossing, beginning as a combination of musicology and anthropology. The more recent discipline of popular music studies has also, from the word go, been predicated upon the notion of border crossing, subsuming at the very least theory and method from sociology, mass communications, and semiotics. In addition, much recent work, including that of Robert Walser, Richard Middleton, Allan Moore, and Alan Durant, has been keenly interested in bringing musicology into the mix, focusing on what I feel to be the most grossly neglected area of popular music studies, the actual sounds of popular music. ${ }^{4}$

Popular music scholars originating within either the culture or music fields find themselves, by necessity, often acquiring in an ad hoc fashion bits and pieces of business and economic theory to enable them to understand the political economy of the record industry. Consequently, terms and concepts such as oligopoly, economy of scale, and vertical integration as well as different models of business organization have slowly forced themselves into the everyday lexicon of many popular music scholars.

I am no exception in this regard, having acquired a piecemeal "scholarly" knowledge of business theory at large. In addition, I am no stranger to the music industry itself. Since 1971 I have actively worked within the industry in a number of capacities, writing for popular music magazines in Canada, Great Britain, and the United States including one published by Canada's major concert promoter which, in an ancillary fashion, provided me with a certain measure of insight into the domain of concert promotion. I have also hosted my own radio shows in both Canada and the United States, been first an employee and later an owner of two record stores and I have been regularly hired by both major and independent labels for the last ten years producing and writing liner notes for historical reissues. Due to this range of experience, I have had the rare opportunity to be a participant-observer in several different domains of the music industry and consequently I have always considered myself fairly well versed in how the political economy of the record industry actually works.

Despite the above, my endeavours to understand the business and economic machinations of Stax Records have revealed that the knowledge I brought to this research, acquired both within academia and pragmatically within the industry itself, was insufficient to understand and consequently interpret and write about the economic history and ultimate bankruptcy of Stax Records. Given the importance of Stax in general and the ramifications the company's bankruptcy had for any number of artists, writers, and producers as well as for soul music at large, coming to a full and accurate understanding of this would seem to be important.

\footnotetext{
4Robert Walser, Running With the Devil: Power, Gender and Madness in Heavy Metal Music (Hanover, N.H.: Wesleyan University Press, 1993); Richard Middleton, Studying Popular Music (Philadelphia: Open University Press, 1990); Allan Moore, Rock: the Primary Text (Buckingham, U.K.: Open University Press, 1993); Alan Durant, Conditions of Music (London: Macmillan, 1984).
} 
The story of Stax is fascinating and has dominated my life for the past ten years. It was the subject of my Ph.D dissertation and since my graduate school days, I have been involved in the reissue of over seventy compact discs of Stax material, have co-directed a documentary on the label, written any number of magazine articles on Stax artists, have published two previous scholarly articles on Stax in Popular Music and Popular Music and Society 5 and my book-length work on the label, Soulsville U.S.A.: The Story of Stax Records, has just been published by Schirmer. ${ }^{6}$ In all of this work, the area I am still struggling to come to grips with is the business machinations that occurred in the final three and a quarter years of the label's history which ultimately brought what had been an incredibly successful business enterprise to its death bed in the final days of 1975 .

Stax was founded in the late 1950s by a country fiddler named Jim Stewart. ${ }^{7}$ Stewart had originally envisioned heading a country and pop record label. It was only after his first eleven pop and country releases had failed abysmally and he had fortuitously situated his studio in an abandoned neighbourhood movie theatre in an area of Memphis that was rapidly turning from white to black that he got involved with rhythm and blues. The musicological and sociological story of the label is long and complex and space does not allow me to recount it in detail here. The quick overview is that one of Stewart's first r \& b recordings, Rufus and Carla Thomas's "Cause I Love You," turned out to be his first hit, selling well enough in the mid-South area to interest Atlantic Records to approach Stax about a national distribution deal. With Atlantic handling marketing, sales, distribution, and promotion, Stax, "the little label that could," developed a readily identifiable sound concocted by an integrated house band. This sound became the blueprint for most of the

5Rob Bowman, "Stax Records: A Musicological Analysis," Popular Music 4, no. 3 (Fall 1995); 285-320; and "Stax Records: A Lyrical Analysis," Popular Music and Society 20, no. 1 (Spring 1996): $1-34$.

6Rob Bowman, Soulsville U.S.A.: The Story of Stax Records (New York: Schirmer, 1997).

7 As well as conducting extensive primary research for the preparation of this article, I have also consulted the following: all relevant issues of Billboard magazine between 1959 and 1979; Fredric Dannen, Hitmen: Power Brokers and Fast Money Inside the Music Business (New York: Times Books, 1990); Clive Davis and James Willwerth, Clive: Inside the Record Business (New York: Ballantine Books, 1974); George Nelson, The Death of Rhythm and Blues (New York: Pantheon Books, 1988); Peter Guralnick, Sweet Soul Music: Rhythm and Blues and the Southern Dream of Freedom (New York: Harper and Row, 1986); all eleven issues of Stax Fax magazine, edited by Deanie Parker and published by Stax Records in 1968 and 1969; John Pepin, The Turnaround (Oklahoma City, Okla.: Western Heritage Books, 1980); Robert A. Sigafoos, Cotton Row to Beale Street: A Business History of Memphis (Memphis, Tenn.: Memphis State University Press, 1979); close to twenty years of the weekly black newspaper Tri-State Defender; Dorothy Wade and Justine Picardie, Music Man: Ahmet Ertegun, Atlantic Records, and the Triumph of Rock ' $n$ ' Roll (New York: W.W. Norton, 1990); Logan H. Westbrooks and Lance A. Williams, The Anatomy of a Record Company: How to Survive the Record Business (self published, 1981); and Jerry Wexler and David Ritz, Rhythm and the Blues: A Life in American Music (New York: Alfred A. Knopf, 1993). The Memphis daily newspapers virtually ignored the existence of Stax Records until about 1966. Coverage was sporadic from 1966 until the success of Shaft in 1971. From 1971 through the demise of the label and the ensuing court battles there was then substantial coverage of Stax Records and AI Bell. I consulted all the relevant articles in Commercial Appeal and Press-Scimitar and made particular use of the material on the Stax Records bankruptcy and Al Bell fraud trials. 
southern soul that followed. Stax artists in this early period included Otis Redding, Booker T. and the MG's, Sam and Dave, Eddie Floyd, Johnnie Taylor, and Albert King. In the 1970s Stax nurtured a second generation of important artists including Isaac Hayes, the Staple Singers, the Dramatics, the Emotions, and Little Milton and, as well, continued to have a steady flow of hits with many of their earlier acts.

Let me attempt to give an overview of Stax's business operations leading up to the 1972 distribution agreement with CBS Records that ultimately drove the label to bankruptcy. Stax was distributed by Atlantic Records from October 1960 through May 1968. Hard though it may be to believe, Atlantic and Stax operated on a handshake deal from 1960 through 1965 at which point the amount of money involved was considerable enough to warrant the formalization of a written contractual agreement. Jim Stewart had grown up in the fraternal, paternalized South. He trusted Atlantic and consequently felt no need to actually read the contract. This may seem unbelievable to those whose knowledge of the Southern mindset is minimal but, in the 1950s and 1960s, this kind of arrangement was not that uncommon below the Mason-Dixon line. In Stewart's mind, if he and Atlantic owner Jerry Wexler had verbally agreed to something, actually reading the contract would not only be unnecessary, it would be downright insulting. Atlantic's lawyers, though, were socialized within a much different cultural system. They, of course, were products of the much more cut throat, the-letter-of-the-contract-is-the-law, he-who-dies-withthe-most-toys-wins mentality of Northern capitalism. Consequently they had inserted a clause into the 1965 agreement that stated if Stax should ever choose to sever the distribution agreement, Atlantic would have the right in perpetuity to all Stax material it had distributed up to that point. In 1968 Atlantic was sold to Warner Brothers for a reported $\$ 17$ million and Stax elected to sever its distribution agreement with the New York-based company. Due to the aforementioned perpetuity clause, terminating the distribution arrangement with Atlantic ultimately meant that in May $1968 \mathrm{Jim}$ Stewart lost the control of his entire back catalog. In many ways, he and his new African-American partner, former disc jockey $\mathrm{Al}$ Bell, were starting all over again from point zero.

One of the first things I needed to understand was that the Stax/Atlantic distribution deal was what was known at that time as a P \& D deal, a production and distribution deal. According to this arrangement, despite what would be assumed by most members of the public and, presumably, most scholars, Stax was a record company in name and appearance only. The truth of the matter was that Stax was just a vanity name and logo used for records that Jim Stewart produced in his own studio in Memphis, Tennessee. Jim Stewart was, in effect, employed by Atlantic as a producer in the same way as any other producer who worked for the label. The only real difference was that Stewart used his own studio, had to pay his musicians and his artists out of his royalty payments and, if Atlantic declined to exercise its right of first refusal on a given recording that Stewart produced, he could elect to distribute it himself. This explains what would otherwise seem to be an unbelievably onerous royalty rate of $12 \%$ of $90 \%$ of the suggested retail price that Atlantic paid to Stax. 
On 6 May 1968 Stax, in effect a brand new label save for whatever goodwill was inherent in the company name, began a short life as a truly independent full-service company. (By full service I mean they handled their own recording, pressing, promotion, publicity and sales.) Distribution was done through a number of regional independent distributors. (Understanding the nature of independent distribution in the post-war period could be a book length study in and of itself and if done would be of great service to popular music scholars.)

In June 1968 Stewart and Bell sold Stax to Gulf and Western, a West Coast conglomerate involved in a multitude of industries including oil, motion pictures, through Paramount Pictures, and the record industry, through Dot Records. Within a year and a half Stewart and Bell announced that they were attempting to purchase the company back from Gulf and Western. They were unhappy with the performance of the $\mathrm{G} \& \mathrm{~W}$ stock that they had been given in lieu of cash and, more importantly, they were aghast at the larger company's desire to distribute Stax product through the branch outlets of G \& W's other record company, Dot Records. It cost them a million dollars more than they had been paid to buy back their own company (incidentally the buyback was partially funded via a loan from the German classical label Deutsche Gramophon in exchange for European distribution rights to Stax product). On 24 July 1970 Stewart and Bell once again owned the company outright. This arrangement would maintain until October 1972. In the intervening two years Stax experienced phenomenal growth, quadrupling its annual sales.

The main conundrum for me to understand and consequently interpret with regard to the political economy of Stax was the nature of the distribution agreement executed between Stax and CBS Records in October 1972. By that summer, Jim Stewart, now co-owning the company with former black disc jockey $\mathrm{Al}$ Bell, had become tired and disillusioned. Stax had grown far beyond the family concept he had initially nurtured and he was spending less time in the studio and more time doing the type of work in offices that he had initially started a record company to avoid. He decided that he wanted to sell his part of the company.

Negotiations ensued with a number of potential partners. Al Bell eventually proposed to CBS that they buy Stewart's half of the company but CBS's lawyers felt that they would run into trouble with the then-current United States antitrust laws. Instead, an agreement was worked out whereby CBS would loan Al Bell 6.7 million dollars which Bell would partially use to buy Jim Stewart's half of the company. In return CBS would have distribution rights to Stax's three main labels: Stax, Volt, and Enterprise.

The first item that was difficult to comprehend as an outsider was why either company would be interested in such a deal. To many observers, CBS seemed like an extremely odd choice to distribute Stax product. While CBS may have been a music industry powerhouse, they had very little experience with or understanding of the black music market which, historically, had always operated in a very different manner from the pop or white market.

The rationale behind the agreement was that, through CBS, Stax would get access to the rack jobbers that largely controlled the record inventories at all 
major department stores. It is important to understand that, at the time, there were no mega record store chains such as Tower, Virgin, and HMV in the United States. Department stores were the major type of retail operation that serviced the majority of white consumers and facilitated sales of large numbers of LPs. Up to this point Stax had been distributed through a variety of independent distributors that had little or no access to anything but independent "Mom and Pop" retail record stores largely located within black neighbourhoods. The majority of business conducted in these stores was in the sale of forty-five's as opposed to the more profitable medium of LPs.

In Al Bell's vision, the CBS deal would facilitate crossover sales of any number of Stax artists, as well as supporting in grand style his desire to expand Stax's efforts in the world of rock, pop, country and jazz. On the CBS side of things, the distribution deal would hopefully force the small Mom and Pop stores that in the main serviced the inner city black population to come to CBS for Stax product and, while doing so, buy all other CBS black-related releases, thereby accessing a segment of the music industry that had heretofore generally eluded CBS.

Unbeknownst to anyone outside CBS, a year earlier the company had commissioned Harvard University to prepare a report as to how CBS could best get into the black market. A number of Harvard MBAs compiled a study that was tabled 11 May 1972 and has since become known within Stax and CBS circles as "The Harvard Report." This document suggested that CBS should, in the best case scenario, buy either Stax or Motown. It went on to say that Stax was the more likely of the two to be purchased but concluded that ultimately this was unlikely as the Harvard MBAs erroneously reported that Gulf and Western still owned Stax. In the event that neither Stax nor Motown could be purchased, the Harvard Report recommended that CBS distribute one of the two labels instead. Perhaps, once an ongoing relationship had been established, CBS would at some future point in time be able to purchase the distributed company. In cementing his deal with Bell and Stax, Clive Davis had accomplished the report's initial recommended plan of action.

In April 1973, five months after the Stax/CBS deal was consummated, CBS, disturbed by questions raised by the U.S. Attorney's Office in Newark, New Jersey, initiated an internal audit. Both CBS and the Attorney's Office were particularly concerned with the activities of Clive Davis's right hand man, David Wynshaw. The federal prosecutors in Newark were interested in a range of issues, foremost among them being payola and the consequent ties between the music industry and organized crime. Wynshaw was found to have set up a number of companies in partnership with Patsy Falcone whom Fredric Dannen describes, in his excellent book Hitman, as "an associate of the Genovese family" crime syndicate. ${ }^{8}$ It turns out Wynshaw and Falcone's "companies" defrauded CBS of tens of thousands of dollars. Davis was asked to fire Wynshaw in April and eventually Wynshaw would find himself facing criminal

8Dannen, Hitmen, 92. 
charges, being sentenced to a year in jail for conspiring with Patsy Falcone to defraud CBS.

On top of this untidy mess, CBS was in a near panic over rumors that the Federal Grand Jury probe, operating under the moniker Project Sound, suspected that the giant corporation might have been involved in payola with a number of black radio stations. If this proved to be true, CBS's valuable television and radio licenses could be in jeopardy. Leaving no stone unturned, while cleaning out Wynshaw's office, CBS uncovered papers that led them to conclude that Clive Davis had also engaged in unscrupulous activities. On 29 May CBS shocked the music industry by terminating Record Division president Davis. That same day Davis was served with a Civil Complaint alleging $\$ 94,000$ worth of expense account violations over the six years that he had been president. On 24 June 1975 Clive Davis was indicted by a Grand Jury for six counts of tax evasion based around these same CBS expense account violations. He would plead guilty to one count and was fined $\$ 10,000$ in September 1976. Fourteen months later he privately settled the civil case that CBS had brought forward.

These events, so far from Memphis, Tennessee, would prove to have dire ramifications for Stax Records. Al Bell had always had reservations about CBS as a corporation. What he termed Clive Davis's "sensitivity" was the only reason he was willing to do business with, to use Bell's terms, such a "white monolith" in the first place.

The nature of the Stax/CBS distribution deal is difficult to understand without specialized knowledge of the record industry of the early 1970s. In its day, it was quite novel. According to Bell, no one but he and Clive Davis truly understood it. Davis and Bell's understanding was that Stax would not be distributed so much by CBS as was then the norm. Rather Stax would be distributing its product through CBS's branches. This was an important distinction. In the simplest terms what it meant is that the CBS distribution machine would be used by Stax to reach the coveted rack jobbers but CBS sales and marketing brass, possessing little or no knowledge about the type of product that Stax specialized in, would in no way be determining marketing, sales or promotional strategy. Instead, Stax's own personnel would continue to fulfill these functions, obviously in as close communication as possible with CBS personnel.

In the seven months that the deal had been in effect prior to Clive Davis's dethronement, an efficient interface had yet to be accomplished. No one at Stax, though, had felt any cause for undue alarm. Davis had suggested that Stax product initially go through the Epic/Columbia Custom Division for an interim period of orientation. One assumed that over time most, if not all, of the bugs would be worked out. When Davis was fired, Stax had not yet been moved out of the Custom Division and put directly through the branches. With Davis's understanding of the deal a moot point after his termination, Stax would remain mired in the Custom Division for as long as CBS continued to distribute their product. 
Neither Davis's replacement, former CBS television executive Irwin Segelstein, nor his underlings understood the nuances of the deal or cared about them. As far as they were concerned Davis had simply made a bad deal. Stax was being paid $\$ 2.26$ per every $\$ 5.98$ list LP that was shipped to CBS. In return for "distributing this product through their branches," CBS would probably make in the neighbourhood of a $15 \%$ profit. When Atlantic had distributed Stax in the 1960 s, Stax had been paid a mere $12 \%$ royalty with Atlantic keeping the majority of the money from each sale. The crucial difference was that the Stax/Atlantic arrangement was for what is known as a $\mathrm{P} \& \mathrm{D}$, production and distribution, deal. Stax was recording the music, but Atlantic was paying all manufacturing as well as most marketing and promotion costs. In the case of the CBS deal, Stax was maintaining responsibility for all of these areas. All CBS was supposed to be doing was distributing the product. Hence the near reversal of the distribution of money.

To put this in perspective, it is worth noting that prior to going with CBS, Stax was selling these same LPs to its network of independent distributors for approximately $\$ 2.40$ per LP. As Al Bell explains it, Stax was actually taking a slight cut in income per sale in exchange for CBS taking them into the rack jobbers. Theoretically this tradeoff would net substantial increases in sales and therefore Stax would ultimately profit from the deal. To the new brass at CBS, Clive Davis should never have agreed to any of this. If any deal was to be worked out with a company like Stax it should have been a straight P \& D deal for a minimal royalty.

This difference in business philosophy and consequently understanding of the agreement that Clive Davis and Al Bell had so optimistically worked out would, within a year, bring the once mighty Stax to its knees and in just over two and a half years force the company into bankruptcy.

Compounding Stax's troubles were two other incidents. In September 1973 U.S. District Court Judge Frederick Lacey issued an order requiring Stax to turn over data to the U.S. Attorney's Office relating to a $\$ 400,000$ kickback scheme involving two former vice-presidents, Herb Kole and Ewell Roussell. Apparently some $\$ 380,000$ of free records and tapes had been sent to distributors in return for kickbacks. A further $\$ 26,000$ had been overpaid to photographers in return for kickbacks.

In the summer of 1973 it was announced that the Internal Revenue Service had been investigating Stax since November 1972. The investigation was precipitated when Stax associate Johnny Baylor was discovered carrying $\$ 130,000$ in cash along with a $\$ 500,000$ check as he got off a flight from Memphis to Birmingham.

By January 1974, the Stax front office had begun to feel there were extremely serious problems with the distribution of their product by CBS. For one reason or another the majority of Stax releases were not getting into stores. When CBS denied that this was the case, Al Bell had his brother Paul Isbell head up a seven person Retail Relations department that simply canvassed several hundred stores across the country asking if they had a demand for Stax product and if they were able to satisfy that demand. Isbell's research con- 
firmed what Stax had been contending all along. CBS was ordering substantial quantities of Stax product but, for one reason or another, most of it was staying in the larger corporation's branch warehouses. CBS argued that (1) Isbell's research was erroneous, Stax product was widely available, and (2) where product was not in stores, it was due to a lack of demand. Further, CBS declared, truckloads of Stax material were being returned and consequently the label was over advanced. Things came to a head in April 1974 when CBS began to withhold $40 \%$ of the money due to Stax on new releases as a reserve against records already paid for that had not sold. The immediate result was that Stax began to experience cash flow problems severely cramping their day to day operations. Their distributor was effectively engaging them in economic strangulation.

In order to combat the shortage of cash caused by CBS's April decision to withhold $40 \%$ of the funds due Stax on new orders, Al Bell had begun to borrow large quantities of money from Union Planters National Bank. Stax had long been a Grade A customer of the bank and Union Planters was only too happy to partake of the added interest payments. Stax used its publishing arm, East Memphis Music, as collateral for the loan as the record division of the company was encumbered by its loan from CBS dating back to October 1972. Obviously this type of solution could only be a temporary one. As long as Stax was unable to realize substantial revenue from its recordings, disaster could only be so far off.

In July things became much worse when CBS ceased remitting funds altogether contending that Stax was ludicrously over advanced. Although they did not know it at the time, Stax would never receive another cent from the New York-based conglomerate. Substantial counter measures being in order, Stax created a new label they called Truth. As far as Stax was concerned, the CBS distribution deal included only the Stax, Volt, and Enterprise labels. All other Stax owned imprints at the time of the deal, namely, Partee, Gospel Truth, and Respect, were tagged specialty labels and were specifically excluded from the agreement. Stax declared Truth to be in the latter category and consequently free and clear of all obligations to CBS. Ironically, as all of these machinations were unfolding, the June 1974 issue of Black Enterprise listed Stax as the fifth largest black business in the United States.

As Stax moved into the closing months of 1974, things seemed to be going from bad to worse. In September, the label's premier artist, Isaac Hayes, sued the company for $\$ 5.3$ million as Stax, experiencing cash flow problems, had been unable to pay him his due royalties. On 16 September the suit was settled out of court but Stax had lost their biggest artist. That same month a check to Little Milton was returned due to insufficient funds. Shortly thereafter a Federal Grand Jury in Memphis, working hand in hand with the payola investigation being carried out by the Newark Grand Jury, issued a subpoena ordering Stax to deliver financial records for the year 1973 by 15 October. The financial records for the company's 1971 and 1972 operations had already been inspected by the Grand Jury and had subsequently been turned over to the 
Internal Revenue Service to determine whether there were additional tax liabilities due the government.

In October Al Bell had gone to New York to meet with CBS executives in an attempt to find a solution to the distribution problem. After a long day of discussions had reached an impasse, Bell retired to his hotel room contemplating what tack to take in the next round of talks. Before the two parties reconvened, Al Bell received a telephone call at his hotel. It was Jim Stewart telling him that a Federal Marshal had just served the company with an injunction and a restraining order which effectively put an end to Stax going outside of the CBS deal. All the while that CBS executives had been ostensibly discussing the situation with $\mathrm{Al}$ Bell in good faith, their lawyers had been preparing a lawsuit. CBS was suing Stax, accusing Stax of ignoring their distribution contract. They claimed that Stax had refused to give CBS product beginning 2 October.

Stax filed a $\$ 67$ million counter suit, claiming anti-trust violations. Stax's position was that CBS deliberately over-ordered albums and then left the records unsold in CBS warehouses, failing to place them in stores where CBS's own product was routinely for sale. Further, Stax claimed that CBS had withheld more than $\$ 2.32$ million due Stax under the 1972 distribution agreement, leaving Stax in a position where it could not meet its payroll and consequently had lost one major artist, Isaac Hayes, and would lose more in the near future. The Civil suit ultimately charged CBS Inc. with breaching its distribution agreement in an effort to gain control of Stax.

In early November Stax's troubles persisted as Richard Pryor sued the company for $\$ 30,000$ in unpaid back royalties. Worse still, Memphis's Union Planters National Bank filed suit against CBS and Stax, fearing that the problem the two record labels were experiencing with each other was jeopardizing what UP alleged to be Stax's $\$ 8.8$ million debt to the bank.

In late winter 1975 Stax settled its differences with CBS, under extreme duress, out of court. CBS agreed to relinquish its rights to distribute Stax product if Stax repaid its debt to CBS by 31 August 1976 . The exact total of the debt was undisclosed, but it exceeded the original \$6 million loan CBS had made to Stax in 1972. CBS agreed to cut the loan in half if it was paid by the agreed upon deadline. Stax, in turn, agreed to let CBS keep $\$ 4.26$ million worth of record inventory that was currently stored in CBS's warehouses. Finally, if Stax failed to pay the debt by the agreed upon date, CBS could once again decide to exercise the right to distribute Stax product, although they were not obligated to do so.

Although Stax was clear of its distribution problem with CBS, it was still in rather desperate straights. The company owed several million dollars to both CBS and Union Planters National Bank. It had lost, or was about to lose, its contract with virtually all of its key artists including Isaac Hayes, the Dramatics, the Emotions, the Staple Singers, and comedian Richard Pryor due to the economic problems it experienced in the latter half of 1974. In some ways, ironically, the label was, for a third time, starting from ground zero. This time, though, Stax was saddled with backbreaking debts and did not have the 
financial resources of a Gulf and Western to use as start-up capital. The odds of survival were not great but Al Bell, Jim Stewart, and several others soldiered on.

Despite bravery and a slew of increasingly desperate measures in the face of what appeared to be insurmountable odds, Stax was losing ground. In September the company's phone was disconnected. That seemed minor compared to the next bit of news as, that same month, Al Bell was presented with a fourteen-count indictment by a Memphis Federal Grand Jury. The indictment charged that Bell, in partnership with bank officer Joseph Harwell, had defrauded Union Planters National Bank of \$1.8 million via fraudulent loans, credit extensions, and overdrafts. Harwell was already in federal prison, having been earlier convicted of embezzling $\$ 284,000$ from the bank. Bell was eventually totally exonerated but, in the meantime, the battle raged on yet another front.

In early December everything started closing in. Union Planters National Bank began foreclosure proceedings against Stax's most profitable subsidiary, the East Memphis Music publishing company, due to a default on a $\$ 3$ million 1973 loan that had been secured with East Memphis's salable assets as collateral. On 5 December, on the steps of the Shelby County Courthouse, East Memphis's assets, including 3,500 copyrights, were put up for auction. Union Planters National Bank was the only bidder, buying the assets of East Memphis Music Co. for the price of the $\$ 3$ million loan.

On 19 December 1975 what remained of Stax was forced into receivership by an involuntary bankruptcy petition orchestrated by the bank and filed by three of Stax's minor creditors: Mayer Myers Paper Co. of Memphis; Star Photo Services, Inc., of Nashville; and Newark Electronics Corp. of Chicago. These creditors were chosen as there could be absolutely no dispute as to their respective claims. Bell and Stewart tried to fight this by attempting to prove solvency but on 12 January 1976 U.S. Bankruptcy Judge William Leffler, at the request of Union Planters National Bank, signed an order closing Stax. Union Planters contended that Stax owed the bank $\$ 8.8$ million, CBS $\$ 11$ million and had collective debts totaling $\$ 30.8$ million. The principals at Stax contended that these amounts were grossly exaggerated. Be that as it may, Stax's studio at 926 East McLemore had been padlocked. Stax, for all intents and purposes, had come to an end. On 22 July 1976 it became official as Stax was ruled irrevocably bankrupt.

On 2 August 1976 Al Bell was cleared of the bank fraud charges brought against him eleven months previous. The Internal Revenue Service never brought charges against Stax or any of its principals. The Newark Payola Probe never saw fit to bring an indictment against Stax. One has to conclude that an extraordinary amount of pressure was brought to bear on Stax by the government with absolutely no foundation. It has to make you wonder why. All Stax was ever guilty of was overextending itself in a Herculean effort to defend itself from what might be viewed as an attempt at a hostile takeover from CBS. A lot of people were severely hurt by all of these events - financially and psychologically. Dozens of employees lost their homes, several went bankrupt, 
a few had their marriages disintegrate under the pressure. None, of course, have ever been compensated.

Did CBS actually conspire to strangle Stax in a hostile takeover attempt? That probably was never Clive Davis's intention and if he had not been deposed perhaps Stax would still be alive. After Davis's termination, it is a conceivable conclusion that CBS was attempting a hostile takeover but equally plausible is a scenario where two parties were stuck with a deal that the larger party sincerely felt should never have been executed. This unfortunate occurrence was further compounded by the two radically different business philosophies the two parties had developed while serving very different demographics. These differences were so great that they effectively precluded the two parties from even being able to productively talk to each other. The natural result was that both acted in their own interest and, as is usually the case in a capitalist system, the smaller concern lost.

$\mathrm{Al}$ Bell and several other Stax employees still cry conspiracy on CBS's part. Depending on who you talk to, this version of the story will also implicate the government suggesting that Stax's political activities led the IRS and a number of Federal Grand Juries to place undue pressure on the label. These political activities included funding Jesse Jackson and radical black film maker Melvin Van Peebles, publicly advocating a pan-Africanist philosophy and allegedly running guns to various African nations.

For me to begin to understand any of this, I had to acquire detailed knowledge of standard late 1960s/early 1970s distribution deals within the industry, both in terms of the financial split and working mechanisms. This is actually very difficult to do as it is virtually impossible to get hold of actual contracts. I also needed to gain an understanding of the differences in the retail marketing of forty-fives versus LPs, of the differences of the marketing of both mediums vis-à-vis black and white consumers and of the differences in the businesses of independent distributors and rack jobbers.

If one attempted to understand the various and sundry economic machinations that occurred over the course of the history of Stax Records by Marxian theory applied on a macro level alone, the conclusions one would come to would be insufficiently nuanced. For example, such a structurally-driven analysis would fail to take into account the peculiarly human and intangible "understanding and philosophy" shared by Al Bell and Clive Davis that theoretically would have made what was a novel deal work and that was, unfortunately, simply lost on Davis's successors. Further, without a detailed analysis on the micro level of the record industry at that time, such an approach would also fail to adequately account for all of the complimentary goals that brought the two companies together in the first place.

That said, despite the fanciful title I gave to this paper in the summer of 1994, an MBA would not necessarily provide all the answers either. In the arena of political economy one has to, as with any other cultural domain, understand whatever is being studied on its own terms. We could not begin to attempt to evaluate all the musics found in North America from the standpoint of functional harmony nor could we attempt to understand social organizations cross-culturally from one grand vantage point. Why would we be naive enough 
to attempt to do that in the domain of political economy? Instead we need to make the effort to acquire a more detailed and sophisticated, temporally-based understanding of the intersection between the local and national political economies of the music industry and we need to take into account individual agency if we wish to gain a deeper understanding of the machinations of the industry and the resulting consequences these machinations have with regard to the production and consumption of the music. To my mind that involves border crossing. Give me my passport.

Questions I still do not understand:

How does a bank allow one small, albeit successful company, to accumulate a debt load of $\$ 30.8$ million?

Al Bell disputes this figure, claiming although it was entered in the court record, it was in reality the sum total of Union Planters' loans to all participants in the Memphis music industry. How does a researcher find out what is really accurate?

Getting access to actual hard dollar facts about any business is difficult. Tax returns are not matters of public record and, needless to say, most companies, big or small, are not interested in letting researchers have access to this material. For that matter, even if one does have access to such documents, they are not necessarily accurate (according to my accountant his discipline is very much an art, not a science - give two accountants the same set of figures and you can have two very different tax returns if your business is complicated in even the slightest degree). Further, even if you could get access to tax returns and they were accurate, you need an MBA to even begin to interpret them!

When owed this amount of money, why would the bank not want to help the company reorganize so that over time it might have a chance of recouping its debt? This seems only logical to me and it is certainly what Stax wanted.

When the bank did foreclose on Stax, why did it sell the company's assets well below market value, recouping only pennies for every dollar it was owed?

Why would CBS or Stax allow the quantities of Stax records, pressed and shipped to CBS, to get so out of alignment with what the sales actually were?

How does one get hold of the Harvard Business Report? This has eluded me and several other researchers for a decade.

Over the course of all this work I have learned how to read contracts with some acumen and I am just beginning to understand Chapter 11 bankruptcy laws in the United States. This has often required interviewing lawyers and accountants. When trying to understand nuances of record production I often interview engineers. When trying to understand nuances of finance and law, it only makes sense to solicit the insights of respective authorities. I have yet to interview IRS officers and Federal judges but I am sure that will come in time.

\section{Abstract}

Stax Records was a record label based in Memphis, Tennessee from the late 1950s through December 1975, when it was forced into involuntary bankruptcy. "So You Want to Be a Rock and Roll Scholar - Well You Need to Get an MBA" uses Stax Records as a case study to problematize what has often been a tendency within popular music scholarship 
to attempt to understand the political economy of the record industry primarily via the mechanical application of Marxist theory on a macro level. In looking in detail at the relationship between CBS Records and Stax from 1972 through 1975, the author concludes that to fully understand the nature of the distribution agreement between the two companies, its ramifications, and the consequent subsequent actions of the various principals involved, all of which eventually led to Stax's bankruptcy, one needs to take into account on a micro level the different modi operandi of independent and major labels, differences in the retail world of black and white America, and individual agency. Finally, all of the above needs to be considered very specifically within a temporal flamework. The final conclusions prove to be significantly different from what would have resulted from solely from a Marxist analysis on a macro level. 